\title{
Crushed bark as a novel soil conditioner for organic plant production
}

\author{
Päivi Kurki, ${ }^{1}$ Elina Nurmi, ${ }^{2}$ Iina Haikarainen, ${ }^{3}$ Riitta Savikurki, ${ }^{3}$ Janne Kaseva, ${ }^{4}$ \\ Kaija Hakala, ${ }^{5}$ Elena Valkama ${ }^{6}$ \\ ${ }^{1}$ Natural Resources Institute Finland (Luke), Department of Natural resources/Plant production, Mikkeli; \\ ${ }^{2}$ Luke, Department of Natural resources/Plant production, Helsinki; ${ }^{3}$ ProAgria Southern Savonia, Mikkeli; \\ ${ }^{4}$ Luke, Department of Natural resources/Applied statistical methods, Jokioinen; ${ }^{5}$ Luke, Department of \\ Natural resources/Plant production, Jokioinen; ${ }^{6}$ Luke, Department of Bioeconomy and environment/ \\ Sustainability science and indicators, Jokioinen, Finland
}

\author{
Highlights \\ - Crushed bark (C/N ratio 78) - a side stream of plywood manufacture - was tested in a two-year organic field experiment. \\ - A one-year (40 $\mathrm{th}^{-1}$ ) application of crushed bark with base ash increased yield and the quality of organic wheat. \\ - Residual effects of a one-year application were pronounced. \\ - Crushed bark application in two successive years provided no benefits for organic wheat production.
}

\begin{abstract}
Due to the reduction of cattle farming, the Finnish agricultural sector currently needs solutions to replace animal manure with new sustainable alternatives. This problem is especially acute for organic farms, which need livestock manure to improve soil fertil-
\end{abstract}

Correspondence: Elena Valkama, Luke, Department of Bioeconomy and environment/Sustainability science and indicators, Tietotie 4, 31600 Jokioinen, Finland.

E-mail: elena.valkama@luke.fi

Key words: Base ash; crushed bark waste; forestry by-products; organic soil conditioner; soil organic carbon; wheat.

Acknowledgements: this research was financed by the Rural Development Programme for Mainland Finland of the European Agricultural Fund for Rural Development of the EU, UPM Plywood Oy as part of the project The field under focus-nutrient circulation and new openings of crop production (Peltohavainto 2016-2019), and as part of the EFSOA project (KS 1798) Environmentally Friendly Smart Organic Agriculture, South-East Finland-Russia Cross-Border Cooperation 2014-2020 Programme, funded by the EU, the Russian Federation, and the Republic of Finland. We thank Dr Galyna Medyna (Luke) for English language editing, and anonymous reviewers for valuable comments.

Received for publication: 27 November 2020.

Revision received: 14 May 2021.

Accepted for publication: 21 May 2021.

(C) Copyright: the Author(s), 2021

Licensee PAGEPress, Italy

Italian Journal of Agronomy 2021; 16:1781

doi:10.4081/ija.2021.1781

This article is distributed under the terms of the Creative Commons Attribution Noncommercial License (by-nc 4.0) which permits any noncommercial use, distribution, and reproduction in any medium, provid- ity and soil organic carbon (SOC) to sustain yield. On the other side, plywood manufacturers aim to find ways to reuse waste fractions such as sandy, wet spruce bark waste. To address both issues, a new soil conditioner was developed from crushed bark (CB) and approved for organic farming by the Finnish Food Authority.

To test the advantages of $\mathrm{CB}$ in organic wheat production, we conducted a two-year field experiment on a farmer's field in Mikkeli (Finland) on loamy sand with moderate soil fertility (C $3.5 \%, \mathrm{C} / \mathrm{N}$ ratio $17, \mathrm{pH} 6.2$ ). $\mathrm{CB}$ (organic matter $80 \%, \mathrm{C} / \mathrm{N}$ ratio 78, $\mathrm{pH}$ 5.7-6.0) at $40 \mathrm{tha}^{-1}$ was applied either in the first year of the experiment or in both years. In addition to $\mathrm{CB}$, half the plots received base ash $\left(4 \mathrm{tha}^{-1}\right)$ obtained from a power plant using wood to maintain the optimal soil $\mathrm{pH}$. All plots were fertilised annually with commercial organic fertilisers. The control plots received no $\mathrm{CB}$ or base ash.

A one-year application of $\mathrm{CB}$ with base ash statistically significantly increased the grain yield by $800 \mathrm{~kg} \mathrm{ha}^{-1}$ and grain $\mathrm{N}$ uptake by about $10 \mathrm{~kg} \mathrm{ha}^{-1}$ in the following growing season compared with the control. In terms of grain yield quality, a one-year application of $\mathrm{CB}$ with or without base ash already showed an improvement of 1000 seed weight by $2 \mathrm{~g}$ in the first year, and the effect was even more pronounced in the second year of the experiment. Hectolitre weight was increased in the following year after application of $\mathrm{CB}$ with base ash. In contrast, a two-year application of $\mathrm{CB}$ either alone or with base ash caused no changes in grain yield, $\mathrm{N}$ uptake, or yield quality compared with the control.

The results indicate that the use of spruce $\mathrm{CB}$ with a high $\mathrm{C} / \mathrm{N}$ ratio as soil conditioner in a large amount may be beneficial in terms of yield and quality when it is applied only once, but not twice in successive years. Future studies need to focus on the long-term residual effects of $\mathrm{CB}$ on productivity, as well as soil parameters such as SOC, cation exchange capacity, and soil microbial activity.

\section{Introduction}

Boreal agricultural soils are rich in organic carbon, amounting to $120-150 \mathrm{Mg} \mathrm{ha}^{-1}$ in topsoil (Minasny et al., 2017). 
Nevertheless, studies based on national inventory data from several decades demonstrate that the arable mineral soils in Finland lose $0.4 \%$ soil $\mathrm{C} \mathrm{yr}^{-1}\left(220 \mathrm{~kg} \mathrm{C} \mathrm{ha}^{-1}\right)$ annually at a $0-15 \mathrm{~cm}$ soil depth (Heikkinen et al., 2013). This goes against the agreed goal "4 per mille" set at the $21^{\text {st }}$ Conference of the Parties to the UN Framework Convention on Climate Change of $4 \%$ increase of annually sequestered soil C (Chabbi et al., 2017). The benefits of soil organic carbon (SOC) for soil fertility, as well as the need to mitigate climate change, have promoted global actions to sequester $\mathrm{C}$ in soils. In Finland, major efforts are being made, especially in connection with the EU's Rural Development Programme (YliViikari, 2019). Ways to add C to soils include conservation agriculture, direct or reduced drilling, year-round biomass coverage, diverse crop rotation, including deep-rooted and perennial crops, cover crops, ploughing of crop residues into the soil instead of removing them, and utilising organic amendments (Jarecki and Lal, 2003; Lal, 2016; Hakala et al., 2016; Valkama et al., 2020).

In organic farming, SOC tends to be higher than in conventional farming because of the typical diverse crop rotations, wintertime crop coverage, especially due to perennial grasses in rotation, and organic amendments such as domestic animal manure, compost, and commercial organic fertilisers (Leifeld and Fuhrer, 2010). Research syntheses and meta-analyses demonstrate that the application of manure to organic and conventional fields can be a promising option for increasing soil C stock by $500 \mathrm{~kg} \mathrm{ha}^{-1} \mathrm{y}^{-1}$ in both types of field (Gattinger et al., 2012; Minasny et al., 2017; García-Palacios et al., 2018).

The availability and distribution of manure in Finland is changing. The number of livestock farms is decreasing, while the size and specialisation of farms is growing (Natural Resources Institute Finland, 2020). Demand for the intensification of animal husbandry has led to a geographical imbalance, with segregation of manure production from crop production in many areas of Finland. Organic farms may therefore lack access to manure because they do not produce any locally and are too geographically distant for profitable manure transport from other parts of the country. The Finnish agricultural sector therefore currently needs solutions to replace animal manure through new sustainable alternatives.

New options for replacing manure include nutrient-rich organic side streams of various food and bioenergy industries, such as meat and bone meal or composts, and reject liquids of bioenergy plants. A novel possibility to improve SOC content and thereby soil fertility is to reuse the side streams of the Finnish forest industry, which generates a total of 27.7 million tonnes of side streams annually (Hassan et al., 2019). Previous studies related to the application of forest industry by-products as soil amendments have mainly focused on pulp and paper mill sludges (Camberato et al., 2006). The positive effects of forest industry by-products on soil quality are primarily due to increased SOC, aggregation, water holding capacity, infiltration rate, and cation exchange capacity (Foley and Cooperband, 2002; Camberato et al., 2006). In boreal conditions, pulp mill sludges could provide a means of slowly adding decomposing organic material to the soil and partly replacing mineral nitrogen fertilisation for spring cereals (Kinnula et al., 2020).

Another side stream of the Finnish forest industry, and especially plywood production, is the bark waste of Picea abies (L.) Karsten, weighing in at 3.8 million tonnes annually (Hassan et al., 2019). Currently, bark waste is used for energy production, as well as for cover materials. The Finnish UPM Plywood company - the largest plywood manufacturer in Europe - aims to find a new way to reuse bark waste as a new soil conditioner after processing it into crushed bark (CB) suitable for the purpose (Suokas, 2020).
We hypothesised that the application of spruce $\mathrm{CB}$, a nutrientpoor amendment with a high $\mathrm{C} / \mathrm{N}$ ratio, in addition to commercial organic fertilisers would increase the grain yield and quality of organic spring wheat, either immediately or with a delay over the following years. Base ash, another side stream of the wood industry produced by the Järvi-Suomen Voima Ltd Ristiina power plant, was also tested for its synergistic effects in providing an optimal $\mathrm{pH}$. Both $\mathrm{CB}$ and base ash have been approved by the Finnish Food Authority (2020) for use in organic farming.

\section{Materials and methods}

\section{Experimental site and weather conditions}

To test the advantages of $\mathrm{CB}$ as a new soil conditioner for organic plant production, we conducted a two-year field experiment on a farmer's fields in Mikkeli, Finland (61 $\left.{ }^{\circ} 40^{\prime} \mathrm{N}, 27^{\circ} 13^{\prime} \mathrm{E}\right)$ in 2017 and in 2018. Experimental soil classified as loamy sand according to the Finnish classification system (Yli-Halla et al., 2000), and sandy Aquic Haplocryod, according to Soil Taxonomy (Yli-Halla and Mokma, 2015), with SOC of 3.5\%, a C/N ratio of 17 , and a $\mathrm{pH}$ of 6.2 (water). The soil fertility of the plough layer $(0-30 \mathrm{~cm})$ was moderate, according to the Finnish Soil Fertility Testing Scheme (SFS-EN 15510:2008, Vuorinen and Mäkitie, 1955) analysed by the commercial company Eurofins Agro (https://www.eurofins.fi/agro/). In the Finnish Soil Fertility Testing Scheme, soil nutrient concentrations are classified as poor, semipoor, tolerable, moderate, good, high, or precarious high. Soil calcium $(\mathrm{Ca})$, phosphorus $(\mathrm{P})$, potassium $(\mathrm{K})$, magnesium $(\mathrm{Mg})$, and sulphur $(\mathrm{S})$ were extracted using acid ammonium acetate-extraction according to the method described by Vuorinen and Mäkitie (1955). Soil Ca, P, K, Mg, and S concentrations averaged 1224 (tolerable), 9.4 (moderate), 89 (tolerable), 130 (moderate), and 7.6 (tolerable) $\mathrm{mg} \mathrm{L}^{-1}$ soil, respectively. A clover-grass mixture was cultivated as a pre-crop in 2016, and spring wheat as the main crop in 2017 and 2018.

The growing seasons differed significantly between the experimental years. In 2017, the thermal growing season started on 1 May and ended on 18 October. The effective temperature sum (Tsum) (the sum of daily mean temperatures above $5^{\circ} \mathrm{C}$ during the growing season) was $1100^{\circ} \mathrm{C}$, which is lower than the long-term average $\left(1340^{\circ} \mathrm{C}\right.$ in $\left.1991-2012\right)$. Precipitation was $310 \mathrm{~mm}$ between May and September, which is similar to the long-term average (315 $\mathrm{mm}$ in 1991-2012). However, the rainfall distribution was uneven, with a very rainy autumn.

In 2018, the growing season started on 25 April and lasted until 22 October. Tsum was unusually high at $1600^{\circ} \mathrm{C}$. Exceptionally unfavourable weather affected plant growth during the growing season, with only $150 \mathrm{~mm}$ rainfall during May-August.

\section{Production and utilisation of bark waste and base ash}

UPM Plywood manufactures high-quality WISA ${ }^{\circledR}$ plywood and veneer products mainly for the construction and transport industries (https://www.wisaplywood.com/). A side stream of the plywood industry is spruce (Picea abies (L.) Karsten) bark waste. It is produced by soaking wood logs in a water pond to soften the tree substance and remove bark for the plywood process (Figure 1A). The bark sediments at the bottom of the soaking pond with forest soil attached to the wood material (Kontinen, 2018). No chemicals are added in the soaking process. The material taken from the water soaking ponds is sifted and crushed (Figure 1B) to 
attain a uniform quality of $\mathrm{CB}$ for application on fields with manure spreading machinery (Figure 1C).

The chemical compositions of $\mathrm{CB}$ and base ash were analysed by the commercial company Eurofins Agro (https://www. eurofins.fi/agro/). The $\mathrm{CB}$ material is nutrient-poor and has a low $\mathrm{pH}$ (organic matter of $80 \%$, a $\mathrm{C} / \mathrm{N}$ ratio of 78 , and a $\mathrm{pH}$ of 5.7-6.0). Fresh CB contained $0.1,2.1,0.16,0.53$, and $0.3 \mathrm{~kg} \mathrm{t}^{-1}$ soluble $\mathrm{N}$, total $\mathrm{N}$, total $\mathrm{P}$, total $\mathrm{K}$, and total $\mathrm{S}$, respectively.

Base ash, another side stream of the wood industry, and produced by the Järvi-Suomen Voima Ltd Ristiina power plant using wood, was also tested for its synergistic effects in providing an optimal pH. Base ash (DM of 99\%, pH of 12.0) contained 3.8, 20.0 , and $0.03 \mathrm{~kg} \mathrm{t}^{-1} \mathrm{DM}$ total $\mathrm{P}$, total $\mathrm{K}$, and total $\mathrm{S}$, respectively, but no N. Both $\mathrm{CB}$ and base ash were approved for organic farming by the Finnish Food Authority (2020).

\section{Establishment of the trial}

Before sowing, both in 2017 and in 2018, the pre-crop (in 2017) or undersown (in 2018) vegetation was crushed, and soil conditioner was applied with manure spreading machinery, followed by ploughing, harrowing, and the sowing and fertilisation of the plots. In 2017, spring wheat (Triticum aestivum (L.), cultivar Wellamo) was sown with a clover-grass mixture on 24 May at a seed rate of 700 germinating seeds per $\mathrm{m}^{-2}\left(260 \mathrm{~kg} \mathrm{ha}^{-1}\right.$ seeds with 1000 seed weight of $27.2 \mathrm{~g}$ ) and $25 \mathrm{~kg} \mathrm{ha}^{-1}$ of clover-grass mixture. The clover-grass mixture was a multi-species mixture, including $84 \%$ of the grass species timothy (Phleum pratense (L.)), perennial ryegrass (Lolium perenne (L.)), meadow fescue (Festuca pratensis (Huds.)), tall fescue (Festuca arundinacea (Schreber)), and 16\% of the clovers red clover (Trifolium pratense (L.)), alsike clover (Trifolium hybridum (L.)), and white clover (Trifolium repens (L.)). In 2017, spring wheat was harvested late, on 27 September due to the rainy autumn. The undersown clover-grass mixture maintained the soil cover during the autumn. In 2018, spring wheat (cultivar Wellamo) was sown at the same rate as in 2017 without an undersown clover-grass mixture on 28 May and harvested on 28 August.

\section{Application of crushed bark and base ash}

Plots, $6 \times 12 \mathrm{~m}$ in size, were randomly assigned one of the following five treatments with four replicates for each treatment, except for the control with 8 replicates in 2018 (Figure 2): i) control: no application of $\mathrm{CB}$ or base ash; ii) application of $\mathrm{CB}$ in the first year (CB-1); iii) application of $\mathrm{CB}$ and base ash in the first year (CBA-1); iv) application of CB in both years (CB-2); v) application of $\mathrm{CB}$ and base ash in both years (CBA-2).

In 2017 and 2018, Randomised Complete Block Design and Balanced Incomplete Block Design, respectively, were carried out. In the first year of the experiment, only treatments of one application could be analysed, but in the following year, all five treatments were included in the analysis. In the second year, five treatments instead of three were therefore compared, and the control plots were doubled and placed side by side due to the farmer's need of the field for the practical use of his cultivation techniques.

Fresh CB (DM of $36 \%$ ) at the rate of $40 \mathrm{t} \mathrm{ha}^{-1}$ was applied between 21 and 25 May either in the first year of the experiment only or in both years. In addition to $\mathrm{CB}$, half the plots received base ash $\left(\mathrm{pH} \mathrm{12.0)}\right.$ of $4 \mathrm{t} \mathrm{ha}^{-1}$ (Figure 2). All treatments and the control plots were fertilised annually with commercial organic fertilisers. Applied commercial fertilisers were produced from organic animal sources and approved for organic farming by the Finnish Food Authority (2020), although the commercial fertiliser products differed between years according to the farmer's cultivation plan.

In $2017,50 \mathrm{~kg} \mathrm{~N} \mathrm{ha}^{-1}$ (Novarbo Arvo) was applied on 24 May
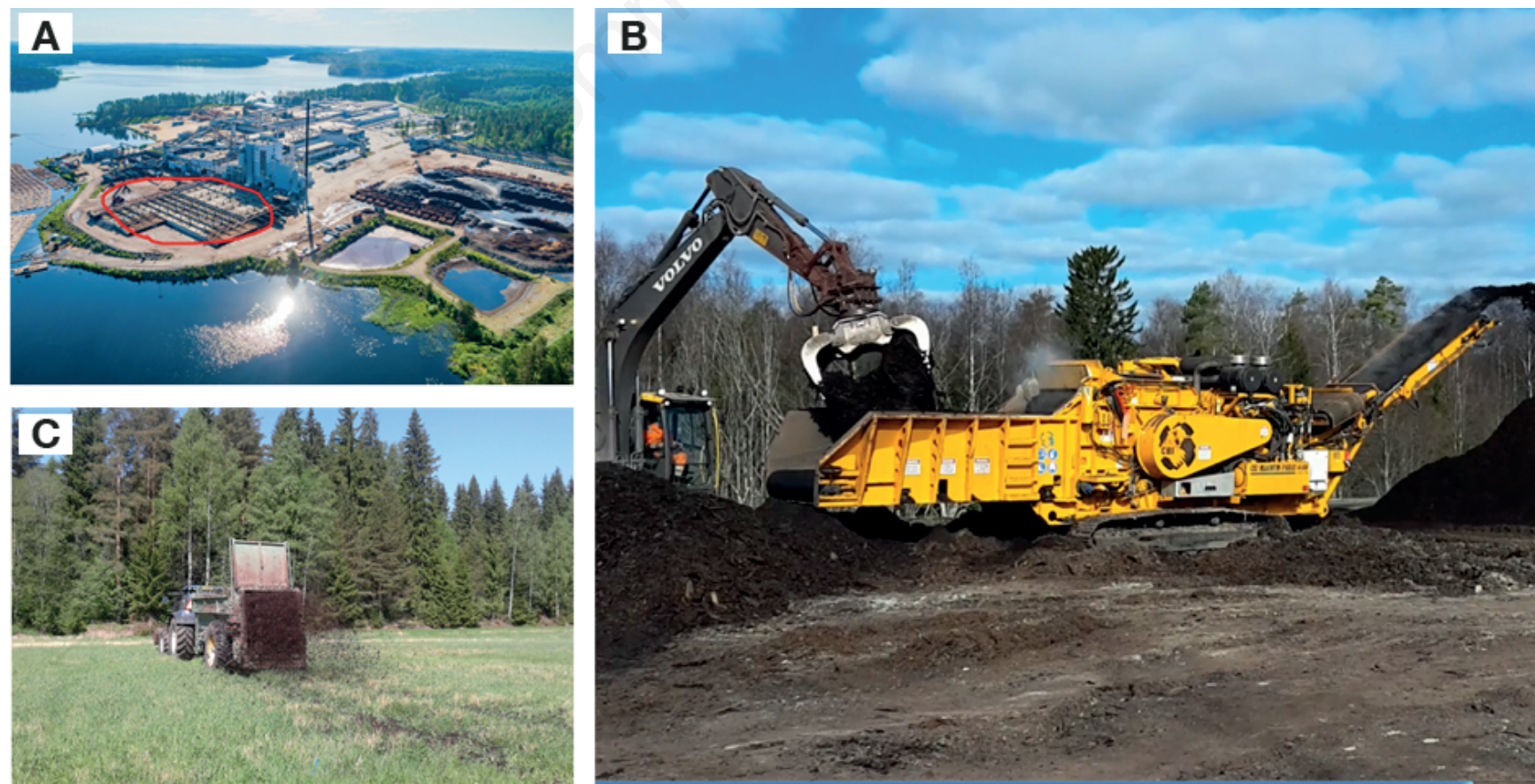

Figure 1. Production and utilisation stages of bark waste, a side stream of the UPM Plywood industry. Spruce (Picea abies (L.) Karsten) wood logs are soaked in water ponds (red circle) to soften the tree substance and remove bark for the plywood process (A), bark sediments are sifted and crushed (B), crushed bark is applied through manure spreading machinery to organic fields in Mikkeli (Finland) in $2018(C)$. Photos (A) and (B) by S. Kontinen and (C) by E. Nurmi. 
and $20 \mathrm{~kg} \mathrm{~N} \mathrm{ha}^{-1}$ (liquid Novarbo Aino) on 21 July to the control and treatments, which were included in the analyses. Other plots were fertilised with $25 \mathrm{~kg} \mathrm{~N} \mathrm{ha}^{-1}$ (Novarbo Arvo) on 24 May and $20 \mathrm{~kg} \mathrm{~N} \mathrm{ha}^{-1}$ (liquid Novarbo Aino) on 21 July. The fertiliser Novarbo Arvo, which is chicken manure and blood-meal based, contained $8,1,2$, and $1 \% \mathrm{~N}, \mathrm{P}, \mathrm{K}$, and $\mathrm{S}$, respectively, and the fertiliser Novarbo Aino contained 1, 0, and 3\% N, P, and K, respectively. Despite the different $\mathrm{N}$ rates applied on 24 May in 2017, there was a low and homogeneous soil residual mineral $\mathrm{N}$ content (sum of ammonium-N and nitrate-N) in the field trial area in the spring of 2018 before the treatments: the soil mineral $\mathrm{N}$ content averaged $2.8 \mathrm{mg} \mathrm{L}^{-1}$ soil $\left(6.9-9.9 \mathrm{~kg} \mathrm{~N} \mathrm{ha}^{-1}\right)$ at the $0-30 \mathrm{~cm}$ soil layer. Soil samples were frozen and analysed by the commercial company Eurofins Agro according to EN 13652.

In $2018,70 \mathrm{~kg} \mathrm{~N} \mathrm{ha}^{-1}$ of Ecolan Agra ${ }^{\circledR}$ was applied to all plots on 28 May. Meat and bone meal-based Ecolan Agra ${ }^{\circledR}$ contained 8, 4,8 , and $4 \% \mathrm{~N}, \mathrm{P}, \mathrm{K}$, and $\mathrm{S}$, respectively. In 2018, all plots received $35 \mathrm{~kg} \mathrm{~S}^{-1}$ from a commercial fertiliser. The $\mathrm{S}$ content of $\mathrm{CB}$ and

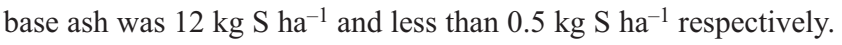
The control, CB-1, and CBA-1 plots therefore received a total of

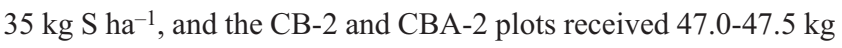
$\mathrm{S} \mathrm{ha}^{-1}$. In the spring of 2018 , before treatments, soil exchangeable S content averaged $5.2 \mathrm{mg} \mathrm{L}^{-1}$ soil (4.4-7.4 $\mathrm{mg} \mathrm{L}^{-1}$ soil) (the commercial company Eurofins Agro) at a soil layer of 0-30 cm, indicating tolerable soil exchangeable $\mathrm{S}$ content (Vuorinen and Mäkitie, 1955) in the field trial area.

\section{Grain yield and quality}

Grain yield, grain $\mathrm{N}$ uptake, grain protein content, grain hectolitre weight, and 1000 seed weight were measured in 2017 and 2018. Additionally, in 2018, grain S content was assessed. Grain yield was harvested by a plot combine harvester and assessed at $15 \%$ moisture content. In 2017, grain yield was analysed from the control, CB-1, and CBA-1 plots due to it being the first year of the experiment (Figure 2A), while in 2018, grain yields were analysed from all treatments (Figure 2B). Grain samples were prepared for quality analyses according to the Official Variety Testing Scheme (Laine et al., 2017), where the 1000 seed weight (g) is the weight of 1,000 seeds of the yield, indicating grain size, and hectolitre weight is the weight of 1001 of the yield, indicating volume weight, both of which are quality measures required in the grain trade. Grain nitrogen $(\mathrm{N})$ content in DM was analysed by NIRS detection and the $\mathrm{HNO}_{3}$ extracted $\mathrm{S}$ content of the grains by ICPOES at the laboratory of the Natural Resources Institute Finland in Jokioinen. Grain N uptake was calculated according to grain DM yield, and grain protein content by multiplying the $\mathrm{N}$ content by a constant of 6.25 .

\section{Statistical analysis}

Statistical analyses were performed by using the GLIMMIX procedure in SAS Enterprise Guide 7.15 (SAS Institute Inc., Cary, NC, USA) separately for each year, due to contrasting weather conditions. In addition, the number of treatments was different: there were three in 2017 (control, CB-1, CBA-1) and five in 2018 (control, CB-1, CBA-1, CB-2, CBA-2), as well as the different

A

\begin{tabular}{|c|c|c|c|c|c|c|c|}
\hline Block & \multicolumn{3}{|c|}{ VII } & \multicolumn{4}{c|}{ VIII } \\
\hline $12 \mathrm{~m}$ & \multicolumn{3}{|c|}{ CB-1 } & CBA-1 & CB-1 & CBA-1 & \\
\hline $4 \mathrm{~m}$ & \multicolumn{5}{|c|}{ V } & \multicolumn{5}{c|}{ VI } \\
\hline $12 \mathrm{~m}$ & \multicolumn{3}{|c|}{ CB-1 } & CBA-1 & CB-1 & CBA-1 & \\
\hline $4 \mathrm{~m}$ & \multicolumn{5}{|c|}{ III } & \multicolumn{5}{|c|}{ IV } & \\
\hline $12 \mathrm{~m}$ & Control & CB-1 & CBA-1 & CB-1 & CBA-1 & Control \\
\hline $4 \mathrm{~m}$ & \multicolumn{5}{|c|}{ I } & & \multicolumn{5}{|c|}{ II } & Control \\
\hline $12 \mathrm{~m}$ & Control & CB-1 & CBA-1 & CB-1 & CBA-1 & $6 \mathrm{~m}$ & $6 \mathrm{~m}$ \\
\hline & $6 \mathrm{~m}$ & $6 \mathrm{~m}$ & $6 \mathrm{~m}$ & $6 \mathrm{~m}$ & $6 \mathrm{~m}$ & $6 \mathrm{~m}$ & \\
\hline
\end{tabular}

B

\begin{tabular}{|c|c|c|c|c|c|c|c|}
\hline Block & & \multicolumn{2}{|c|}{ VII } & \multicolumn{4}{|c|}{ VIII } \\
\hline $12 \mathrm{~m}$ & & CB-1 & CBA-1 & CB-1 & CBA-1 & Control & Control \\
\hline $4 \mathrm{~m}$ & & \multicolumn{2}{|c|}{ V } & \multicolumn{4}{|c|}{ VI } \\
\hline $12 \mathrm{~m}$ & & CB-1 & CBA-1 & CB-1 & CBA-1 & Control & Control \\
\hline $4 \mathrm{~m}$ & & \multicolumn{2}{|c|}{ III } & \multicolumn{4}{|c|}{ IV } \\
\hline $12 \mathrm{~m}$ & & CB-2 & CBA-2 & CB-2 & CBA-2 & Control & Control \\
\hline $4 \mathrm{~m}$ & & \multicolumn{2}{|c|}{ I } & \multicolumn{4}{|c|}{ II } \\
\hline $12 \mathrm{~m}$ & & CB-2 & CBA-2 & CB-2 & CBA-2 & Control & Control \\
\hline & $6 \mathrm{~m}$ & $6 \mathrm{~m}$ & $6 \mathrm{~m}$ & $6 \mathrm{~m}$ & $6 \mathrm{~m}$ & $6 \mathrm{~m}$ & $6 \mathrm{~m}$ \\
\hline
\end{tabular}

Figure 2. Plot map of crushed bark experiment conducted on a farmer's field in Mikkeli (Finland). Randomised complete block design was used in 2017 (A) and balanced incomplete block design in 2018 (B), respectively. The five treatments used were: the control without crushed bark or base ash application; application of crushed bark in the first year (CB-1); application of crushed bark and base ash in the first year (CBA-1); application of crushed bark in both years (CB-2); and application of crushed bark and base ash in both years (CBA-2). Measurements were recorded only from the control, and treatments marked with green in (A), while from all plots in (B). Blocks are marked with Roman numerals. 
plots serving as controls in 2017 and in 2018 (Figure 2). To compare treatments, a linear mixed model was used with blocks as a random effect and treatments as a fixed effect. Each row was divided into two blocks to improve the power of the design. The assumption of equal variances of treatments was rejected for hectolitre weight based on a likelihood ratio test.

The assumption of normality of residuals was studied graphically from multiple residual plots and found to be adequate. The restricted maximum likelihood (REML) estimation method was used, and the degrees of freedom were calculated using the
Kenward-Roger method (Kenward and Roger, 2009). Tukey's method was used for pairwise comparisons of means, with a significance level of $\alpha=0.05$ (Westfall et al., 2011).

\section{Results}

A one-year application of CB (CB-1) had no effect on organic spring wheat grain yields ( $15 \%$ grain moisture) in either experimental year compared with the control (Figure 3A). However, a
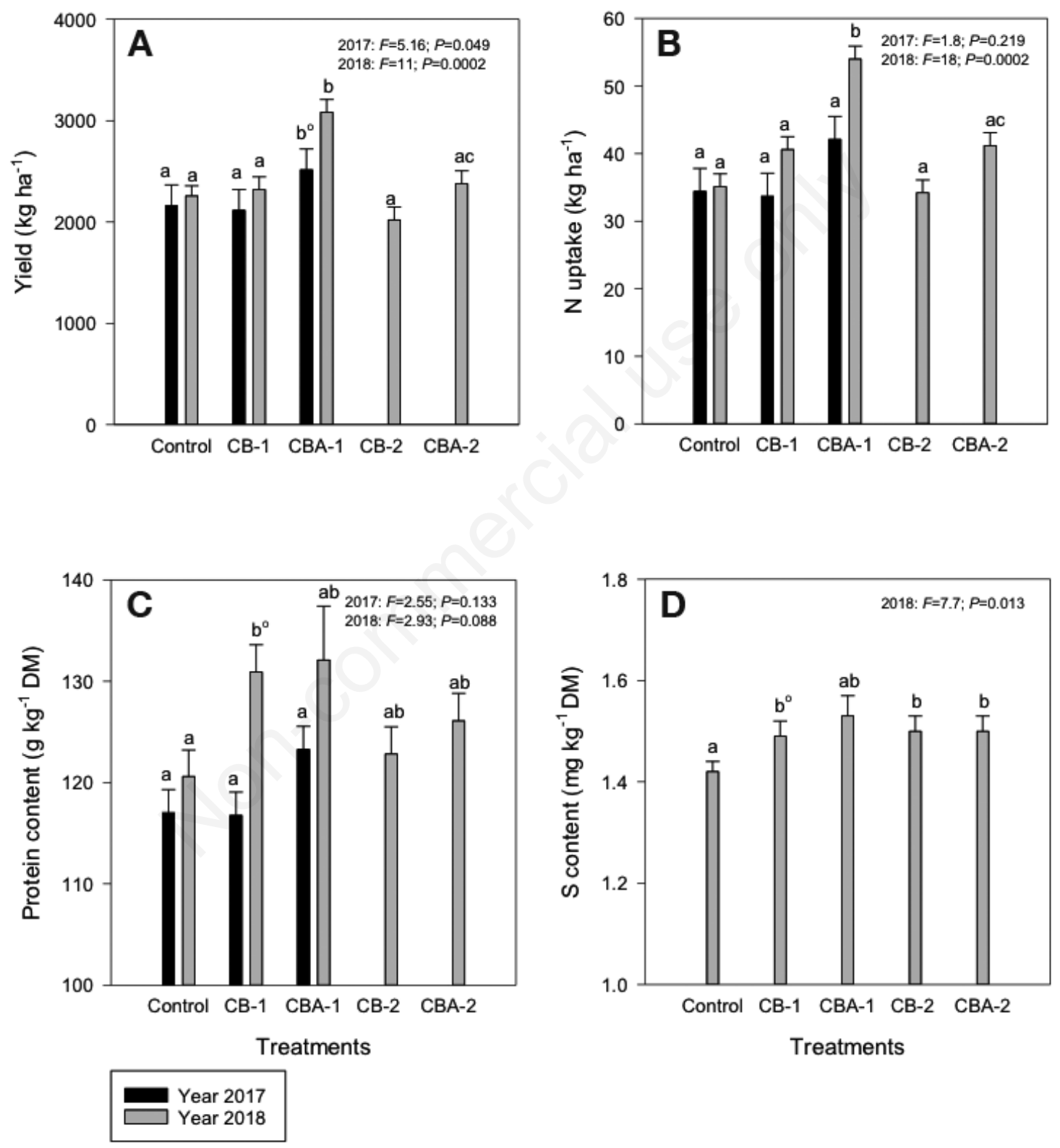

Figure 3. Effect of soil conditioner on grain yield of $15 \%$ moisture (A), grain $\mathrm{N}$ uptake (B), grain protein content (C) and grain $\mathrm{S}$ content (D) of organic spring wheat in 2017 and 2018. Each bar represents the mean $( \pm$ SE) of 4 replicates. Within each year, columns marked by a different letter are significantly different at $\mathbf{P}<0.05$ (Tukey's multiple comparison test). Letters followed by o indicate columns that are significantly different at $\mathrm{P}<0.1$. The control, neither crush bark nor base ash; $\mathrm{CB}-1$, application of crushed bark in the first year; CBA-1, application of crushed bark and base ash in the first year; CB-2, application of crushed bark in both years; CBA2, application of crushed bark and base ash in both years. All treatments and the control were fertilised annually with commercial organic fertilisers. 
one-year application of $\mathrm{CB}$ with base ash (CBA-1) increased the grain yield by $355 \mathrm{~kg} \mathrm{ha}^{-1}(\mathrm{P}=0.06)$ in the first year and by $800 \mathrm{~kg}$ $\mathrm{ha}^{-1}(\mathrm{P}=0.0003)$, reaching $3100 \mathrm{~kg} \mathrm{ha}^{-1}$, in the second year of the experiment (Figure 3A). A two-year application of $\mathrm{CB}$ either alone (CB-2) or with base ash (CBA-2) caused no yield change compared with the control, but a significant yield reduction compared with CBA-1.

The patterns for grain $\mathrm{N}$ uptake were similar to those of the yields (Figure 3B). Compared with the control, the largest increase in grain $\mathrm{N}$ uptake, about $10 \mathrm{~kg} \mathrm{ha}^{-1}(\mathrm{P}<0.0001)$, was observed for CBA-1 in the second year of the experiment, while the other treatments had no statistically significant effect.

Grain protein content increased by $10 \mathrm{~g} \mathrm{~kg}^{-1} \mathrm{DM}$ at CB-1 $(\mathrm{P}=0.06)$ compared with the control in the second experimental year (Figure 3C). No other treatments in the first or second year of the experiment had a statistically significant impact on grain protein content. In 2018, an increase in grain S content was recorded in all treatments compared with the control (Figure 3D). However, no statistically significant differences were found between treatments (Figure 3D). Following the application of the CB-1 and CBA-1 treatments, the 1000 seed weight of wheat already showed an improvement of $2 \mathrm{~g}$ in the first year, and the effect was also pronounced in the second year of the experiment (Figure 4A). In contrast, the application of CB-2 and CBA-2 had no effect on the 1000 seed weight. Among all treatments, only CBA-1 had a positive effect $(\mathrm{P}=0.049)$ on hectolitre weight in the second year of the experiment compared with the control (Figure 4B).

\section{Discussion}

In this study, we tested the hypothesis that the application of spruce $\mathrm{CB}$, a nutrient-poor amendment with a high $\mathrm{C} / \mathrm{N}$ ratio, in addition to commercial organic fertilisers, would increase the grain yield and quality of organic spring wheat, either immediately or with a delay in subsequent years.

To our knowledge, spruce bark as a soil conditioner has not been studied in the last 20 years. There is scant mention of this topic dating from the last century, when Roletto et al. (1985) studied the humification of spruce bark to identify the possibility of recycling industrial residues and using them as plant substrates or organic fertilisers. The authors stressed that spruce bark was a very stable material due to its low nutrient content, low $\mathrm{pH}$, and the large amounts of lignin, fats, resins, and waxes, but in mixing it with manure, favoured its mineralisation and $\mathrm{N}$ release.

Supporting our hypothesis, crushed bark and base ash (CBA1) tended to improve the yield already in the first year of application compared with the control (Figure 3A). In accordance with this, the 1000 seed weight of wheat was significantly increased (Figure 4A), as also shown in earlier experiments with different organic soil amendments (Mohamed et al., 2019).

However, in our experiment the 1000 seed weight was much lower (24-30 g), and the response to the soil conditioner was about 7-8\%, while in the experiment by Mohamed et al. (2019), the 1000 seed weight and the response to amendment were higher (36-46 g and $13-22 \%$ respectively). This difference may have been due to
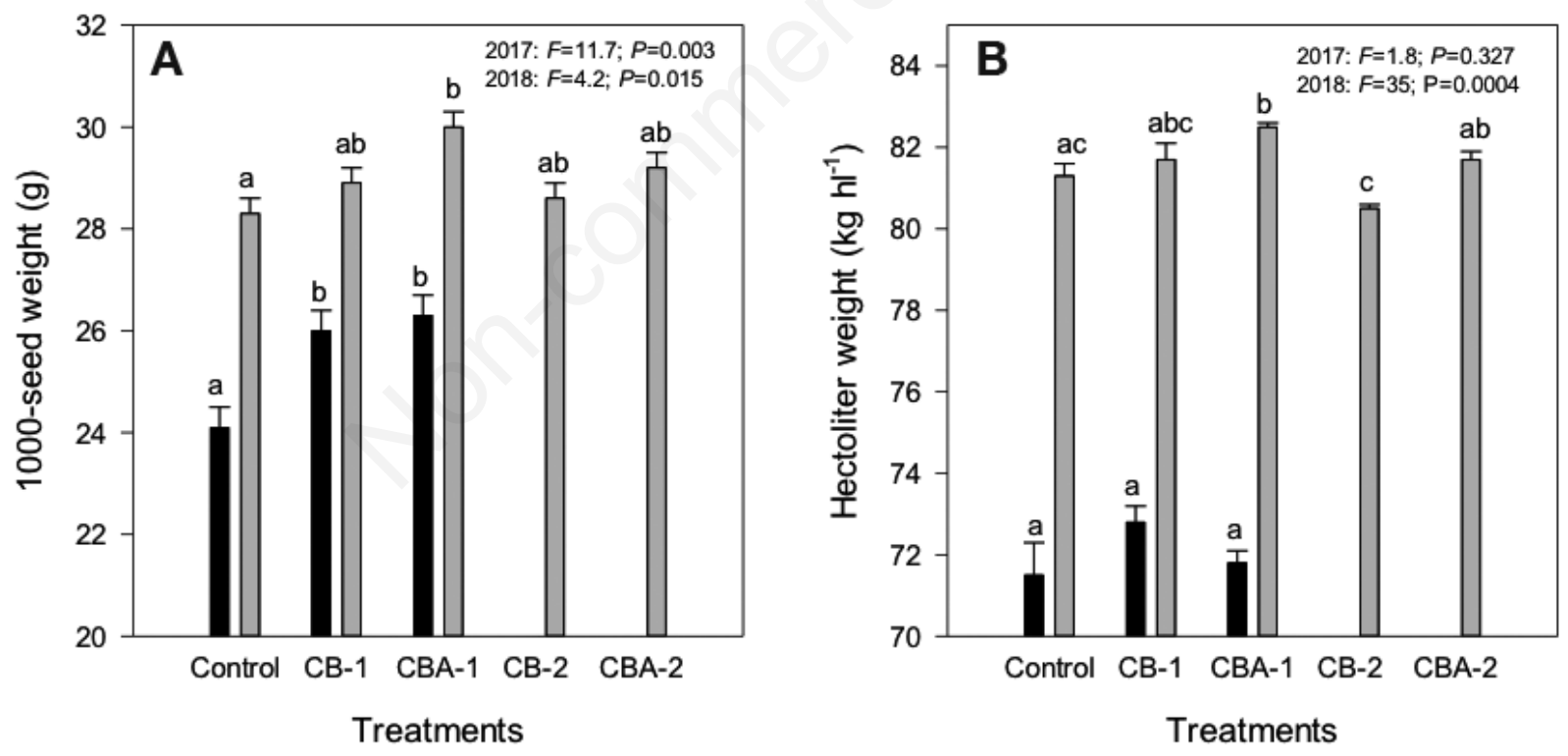

Year 2017

Year 2018

Figure 4. Effect of soil conditioner on 1000 seed weight (A) and grain hectolitre weight (B) of organic spring wheat in 2017 and 2018. Each bar represents the mean $( \pm S E)$ of 4 replicates. Within each year, columns marked by a different letter are significantly different at $\mathbf{P}<0.05$ (Tukey's multiple comparison test). The control, neither crush bark nor base ash; CB-1, application of crushed bark in the first year; CBA-1, application of crushed bark and bottom ash in the first year; CB-2, application of crushed bark in both years; CBA-2, application of crushed bark and base ash in both years. All treatments and the control were fertilised annually with commercial organic fertilisers. 
the short growing season in Finland, which requires the use of crop varieties with a short growing time and thus often low productivity.

However, the largest benefit for organic wheat yield and quality was obtained in the second year of the CBA-1 treatment (Figures 3A and 4A-B). It should be noted that unlike the common practice in organic production, spring wheat monoculture was sown during two successive years in 2017 and in 2018. Moreover, in the second year of the experiment, crops were exposed to adverse weather conditions. Nevertheless, wheat grain yield was as high as $3100 \mathrm{~kg} \mathrm{ha}^{-1}$ in the CBA-1 application, while the yield in the control was only about $2250 \mathrm{~kg} \mathrm{ha}^{-1}$ (Figure 3A). A single application of $\mathrm{CB}$ and base ash was therefore shown to provide a residual effect on both grain yield and quality in the year after application.

Several mechanisms underlying the observed yield improvement under CBA-1 may be relevant. Probably contained in base ash, the additions of $\mathrm{P}$ and $\mathrm{K}$ promoted crop growth, and therefore $\mathrm{N}$ uptake (Figure 3B), and moreover, the high $\mathrm{pH}$ (12) of base ash was intended to neutralise the effect of the low $\mathrm{pH}$ (5.8) of CB. The improved crop production may also be attributed to the synergetic effect of the soil conditioner, and added to each treatment, organic fertiliser, when improved soil structure favoured $\mathrm{N}$ availability for organic wheat as indicated by increased $\mathrm{N}$ uptake and protein content (Figure 3B and C). In addition, it cannot be excluded that during the following season, crop-available nutrients were released through the slow mineralisation of $\mathrm{CB}$ due to its high $\mathrm{C} / \mathrm{N}$ ratio, which was equal to 78 .

The previous study by Curnoe et al. (2006) showed that application of paper mill soil conditioner with a relatively low $\mathrm{C} / \mathrm{N}$ ratio increased corn yields, even in the absence of mineral fertiliser, suggesting the mineralisation of soil conditioner already during the growing season of application. Moreover, the total $\mathrm{N}$ content measured in the plant tissues was greater in the plants from the treated plots, indicating that more $\mathrm{N}$ was available for uptake by the corn plants during the growing season in which soil conditioner was added.

However, the use of $\mathrm{CB}$ in large amounts in two successive years, as in this study, either alone (CB-2) or with base ash (CBA2 ), seemed to provide no benefits for organic grain production (Figures 3 and 4), although an increase in grain $\mathrm{S}$ content was recorded in all treatments compared with the control (Figure 3D). The results suggest that the largest benefits for organic plant production can be obtained through a single application of $\mathrm{CB}$ with base ash, and that the highest benefits are mostly achieved in the year following the application. Similarly, Larney and Angers (2012) concluded that application rates for soil amelioration and biomass production were important, and single large applications of organic amendments could accelerate soil productivity.

Use of organic by-products as soil amendments in agricultural production exemplifies a strategy for converting waste to resources (Foley and Cooperband, 2002). Due to the evident benefits for industries of reusing side streams as valuable products and for world safety in terms of climate change mitigation, the use of these amendments for agricultural fields should be subsidised, at least partly, because profits for farmers are neither certain nor evident, although they bear the workload and expenses of the management measures.

\section{Conclusions}

The results of this two-year field experiment on organic spring wheat indicate that the use of spruce $\mathrm{CB}$ with a high $\mathrm{C} / \mathrm{N}$ ratio as soil conditioner in large amounts, in addition to base ash and organic fertiliser, may be beneficial in terms of yield and quality when it is applied once, but not twice, during successive years. Since the effects were more pronounced in the year following application, it seems there is a time lag between CB application and its effects on cereal productivity due to its high $\mathrm{C} / \mathrm{N}$ ratio, causing slow mineralisation and release of crop-available nutrients. The synergetic effect of the soil conditioner and added organic fertiliser may also be indicated when improved soil structure favours $\mathrm{N}$ availability for organic wheat. Future studies need to focus on the long-term residual effects of $\mathrm{CB}$ on productivity, as well as soil parameters such as SOC, cation exchange capacity, and soil microbial activity.

\section{References}

Camberato JJ, Gagnon B, Angers DA, Chantigny MH, Pan WL, 2006. Pulp and paper mill by-products as soil amendments and plant nutrient sources. Can. J. Soil Sci. 86:641-53.

Chabbi A, Lehmann J, Ciais P, Loescher HW, Cotrufo MF, Don A, Sanclements M, Schipper L, Six J, Smith P, Rumpel C, 2017. Aligning agriculture and climate policy. Nat. Clim. Chang. 7:307-9.

Curnoe WE, Irving DC, Dow CB, Velema G, Unc A, 2006. Effect of spring application of a paper mill soil conditioner on corn yield. Agron. J. 98:423-9.

Finnish Food Authority, 2020. [In Finnish]. Available from: https://www.ruokavirasto.fi/globalassets/viljelijat/luomutilat/1 annoite-ja-torjunta-aine/luomulannoiteluettelo-2020-8.pdf

Foley BJ, Cooperband LR, 2002. Paper mill residuals and compost effects on soil carbon and physical properties. J. Environ. Qual. 31:2086-95.

García-Palacios P, Gattinger A, Jorgensen HB, Brussaard L, Carvalho F, Castro H, Clément J-C, De Deyn G, d'Hertefeldt T, Foulquier A, Hedlund K, Lavorel S, Legay N, Lori M, Mäder P, Martínez-Garcia LB, da Silva PM, Muller A, Nascimento E, Reis F, Symanczik S, Sousa JP, Rubén M, 2018. Crop traits drive soil carbon sequestration under organic farming. J. Appl. Ecol. 55:2496-505.

Gattinger A, Muller A, Haeni M, Skinner C, Fliessbach A, Buchmann N, Mäder P, Stolze M, Smith P, Scialabba NEH, Niggli U, 2012. Enhanced topsoil carbon stocks under organic farming. PNAS 109:18226-31.

Hakala K, Heikkinen J, Sinkko T, Pahkala K, 2016. Field trial results of straw yield with different harvesting methods and modelled effects on soil organic carbon. A case study from Southern Finland. Biomass Bioenerg. 95:8-18.

Hassan MK, Villa A, Kuittinen S, Janis J, Pappinen A, 2019. An assessment of side-stream generation from Finnish forest industry. J. Mater. Cycles Waste Manag. 21: 265-80.

Heikkinen J, Ketoja E, Nuutinen V, Regina K, 2013. Declining trend of carbon in Finnish cropland soils in 1974-2009. Global Change Biol. 19:1456-69.

Jarecki MK, Lal R, 2003. Crop management for soil carbon sequestration. CRC Crit. Rev. Plant. Sci. 22:471-502.

Kenward MG, Roger JH, 2009. An improved approximation to the precision of fixed effects from restricted maximum likelihood. Comput. Stat. Data Anal. 53:2583-95.

Kinnula S, Toivonen M, Soinne H, Joona J, Kivelä J, 2020. Effects of mixed pulp mill sludges on crop yields and quality. Agric. 
Food Sci. 29:276-86.

Kontinen S, 2018. Hautomokuori vaneritehtaan sivutuotteena [In Finnish]. Available from: https://www.maajakotital ousnaiset.fi/sites/default/files/attachment/hautomokuori_vaneritehtaan_sivutuotteena_21032018_sanna_kontinen.pdf

Laine A, Högnäsbacka M, Niskanen M, Ohralahti K, Jauhiainen L, Kaseva J, Nikander H, 2017. Results of the Official Variety Trials 2009-2016. Luonnonvara- ja biotalouden tutkimus 1/2017. Available from: https://jukuri.luke.fi/bitstream/handle/10024/537999/lukeluobio_1_2017.pdf?sequence=6\&isAllo wed $=\mathrm{y}$

Lal R, 2016. Soil health and carbon management. Food Energy Secur. 5:212-22.

Larney FJ, Angers DA, 2012. The role of organic amendments in soil reclamation: a review. Can. J. Soil Sci. 92:19-38.

Leifeld J, Fuhrer J, 2010. Organic farming and soil carbon sequestration: what do we really know about the benefits? Ambio 39:585-99.

Minasny B, Malone BP, McBratney AB, Angers DA, Arrouays D, Chambers A, Chaplot V, Chen ZS, Cheng K, Das BS, Field DJ, Gimona A, Hedley CB, Hong SY, Mandal B, Marchant BP, Martin M, McConkey BG, Mulder VL, O’Rourke S, Richerde-ForgesInakwu AC, Odeh I, Padarian J, Paustian K, Pan G, Poggio L, Savin I, Stolbovoy V, Stockmann U, Sulaeman Y, Tsui CC, Vågen TG, van Wesemael B, Winowiecki L, 2017. Soil carbon 4 per mille. Geoderma 292:59-86.

Mohamed MF, Thalooth AT, Elewa TA, Ahmed AG, 2019. Yield and nutrient status of wheat plants (Triticum aestivum) as affected by sludge, compost, and biofertilizers under newly reclaimed soil. Bull. Natl. Res. Cent 43:31.

Natural Resources Institute Finland, 2020. Official Statistics of Finland. Structure of agricultural and horticultural enterprises 2019. Available from: https://stat.luke.fi/en/

Roletto E, Cerrutti M, Barberis R, 1985. Investigation on humic substances from decomposing spruce bark. Agric. Wastes $13: 137-48$.

Suokas J, 2020. From the bottom of a soaking pond to a commercial soil conditioner. Available from: https://www.upm. com/news-and-stories/articles/2020/03/from-the-bottom-of-asoaking-pond-to-a-commercial-soil-conditioner/

Valkama E, Kunypiyaeva G, Zhapayev R, Karabayev M, Zhusupbekov E, Perego A, Schillaci C, Sacco D, Moretti B, Grignani C, Acutis M, 2020. Can conservation agriculture increase soil organic carbon? A modelling approach. Geoderma 369:114298.

Vuorinen J, Mäkitie O, 1955. The method of soil testing in use in Finland. Agrogeol. Publ. 63:1-44.

Westfall P, Tobias RD, Wolfinger RD, 2011. Multiple comparisons and multiple tests using SAS. SAS Publishing, USA.

Yli-Halla M, Mokma DL, 2015.Classification of soils of Finland according to Soil Taxonomy. Soil Survey Horiz. 40:59-69.

Yli-Halla M, Mokma DL, Peltovuori T, Sippola J, 2000. [Agricultural soil profiles in Finland and their classification]. Maatalouden tutkimuskeskuksen julkaisuja. Series A 78. $32 \mathrm{p}$ [Abstract in English].

Yli-Viikari A, 2019 (Ed.). Maaseutuohjelman (2014-2020) ympäristöarviointi. Luonnonvara- ja biotalouden tutkimus 63/2019. Luonnonvarakeskus, Helsinki, Finland [In Finnish] 